\title{
TINGKAT PENGETAHUAN IBU TENTANG DIARE PADA ANAK DI PUSKESMAS BAHU MANADO
}

\author{
${ }^{1}$ Stephany Y. Motto \\ ${ }^{2}$ Nurhayati Masloman \\ ${ }^{2}$ Jeannete Ch. Manoppo \\ ${ }^{1}$ Kandidat Skripsi Ilmu Kesehatan Anak Fakultas Kedokteran Universitas Sam Ratulangi \\ ${ }^{2}$ Bagian Ilmu Kesehatan Anak Fakultas Kedokteran Universitas Sam Ratulangi \\ Email : funny_lupzz@yahoo.com
}

\begin{abstract}
Diarrhea is a disease caused by an infection that a change in stool consistency from soft to liquid, and increased frequency of bowel movements is three times or more a day. Health ministry survey the incidence of diarrhea appears to have declined. Knowledge of the mother of one effect on the incidence of diarrhea in child, where as this study has not been done in the city of Manado. Objective: This study aims to know the description of the basic knowledge of mothers about diarrhea to child in Manado. This study is a descriptive study. Data collection was conducted in November-December 2012 at primary health center (PHC) Bahu in Manado. Sample of 77 respondents. Methodology: Instrument in the form of questionnaires to assess levels of knowledge and then descriptively in tabular form. Result: The results showed that maternal knowledge about diarrhea in children is good, amounting $55.8 \%$. Conclution: this study concluded that mother's level of knowledge of both the senior high school because most respondents gained is passed senior high school, so we suggested that the relevant agencies can provide more counseling about the importance of knowledge about diarrhea.
\end{abstract}

Keywords : Knowledge, Mothers in Manado, Diarrhea.

\begin{abstract}
Abstrak: Diare merupakan penyakit yang disebabkan oleh infeksi yang terjadi perubahan konsistensi tinja dari lembek menjadi cair dan bertambahnya frekuensi buang air besar yaitu 3x atau lebih dalam sehari. Berdasarkan Survei Kementrian Kesehatan angka kejadian diare tampak menurun. Pengetahuan Ibu salah satu yang berpengaruh terhadap kejadian diare pada anak, sedangkan penelitian seperti ini belum pernah dilakukan di Kota Manado. Tujuan: Penelitian ini bertujuan untuk mengetahui tingkat pengetahuan Ibu tentang diare pada anak di Puskesmas. Penelitian ini merupakan penelitian deskriptif. Pengumpulan data dilakukan pada bulan N0vember-Desember 2012 di puskesmas Bahu Manado. Sampel 77 responden. Metodologi: Instrument berupa kuisioner untuk menilai tingkat pengetahuan dan kemudian secara deskriptif dalam bentuk tabel. Hasil: penelitian menunjukkan bahwa pengetahuan Ibu tentang diare pada anak yaitu baik yang berjumlah 55.8\%. Simpulan: penelitian ini menyimpulkan bahwa tingkat pengetahuan Ibu itu baik di tingkat SMA dikarenakan responden paling banyak adalah lulus SMA, dan disarankan agar instansi yang terkait dapat memberikan penyuluhan lebih banyak tentang pentingnya pengetahuan tentang diare.
\end{abstract}

Kata Kunci : Pengetahuan, ibu di kota Manado, diare.

Tingkat Pengetahuan atau Pendidikan merupakan salah faktor yang mempengaruhi derajat kesehatan masyarakat, hal ini disebabkan karena pengetahuan dan pendidikan yang rendah di masyarakat mengakibatkan banyak sikap dan perilaku yang mendorong timbulnya penyakit infeksi dan penyakit gizi. ${ }^{1}$ 
Di Asia dan diseluruh dunia diare menempati urutan ketiga (15\% dan 17\%) $)^{2,3}$ Diare merupakan salah satu penyakit infeksi utama yang menyerang anak balita $(>1$ Bulan sampai $<5$ Tahun) di Indonesia, dan merupakan salah satu penyebab kesakitan dan kematian di beberapa Negara berkembang. Bila penderita diare banyak sekali kehilangan cairan tubuh maka hal ini dapat menyebabkan kematian terutama pada bayi dan anak-anak usia dibawah lima tahun ${ }^{4}$

Di Indonesia berdasarkan hasil riset kesehatan dasar yang dilakukan oleh Kemenkes Badan Litbankes pada tahun 2007, penyakit diare menjadi penyebab utama kematian bayi $(31,4 \%)$ dan anak balita $(25,2 \%)^{5}$. Berdasarkan hasil survey morbiditas diare yang dilakukan Kementerian Kesehatan sejak 1996-2010, angka kesakitan diare meningkat dari tahun 1996-2006, kemudian menurun pada tahun 2010. Pada tahun 2010, angka kesakitan diare sebesar 411per1000 penduduk. Angka ini mengalami sedikit penurunan dibandingkan tahun 2006 sebesar 423per1000 penduduk. Selengkapnya angka kesakitan diare sebagai berikut: tahun 1996 280per1000 penduduk, tahun 2000 301per1000 penduduk, tahun 2003 374per1000 penduduk, tahun 2006 423per1000 penduduk, tahun 2010 411per1000 penduduk. ${ }^{5}$

Menurut World Health Organization (WHO), penyakit diare adalah suatu penyakit yang ditandai dengan perubahan bentuk dan konsistensi tinja yang lembek sampai mencair dan bertambahnya frekuensi buang air besar yang lebih dari biasa, yaitu 3 kali atau lebih dalam sehari yang mungkin dapat disertai dengan muntah atau tinja yang berdarah. Penyakit ini paling sering dijumpai pada anak balita, terutama pada 3 tahun pertama, dimana seorang anak balita bisa mengalami 1-3 episode berat. ${ }^{6}$

Selain angka kesakitan yang relative tinggi di Provinsi Sulawesi Utara, penyakit diare merupakan penyakit yang potensial yang menimbulkan Kejadian luar biasa (KLB). Tahun 2005 jumlah kasus diare sebanyak 18.110 kasus, dengan Insiden Rate 8,5per1000 penduduk, tahun 2006 jumlah kasus diare sebanyak 22.794 kasus, dengan Insiden Rate 10,7per1000 penduduk, tahun 2007 jumlah kasus diare 27.394 kasus, dengan Insiden Rate 12,5per1000 penduduk. Sedangkan tahun 2008 jumlah kasus diare 19.286 kasus, dengan Insiden Rate 7,9per1000 penduduk. Case Fatality Rate berada dibawah 0,05\% dengan angka kematian absolute tertinggi pada tahun 2007 sebanyak 8 orang. ${ }^{5}$

Salah satu faktor yang ditenggarai berkontribusi terhadap tingginya kejadian diare dengan berbagai tingkatan atau gradasinya adalah belum optimalnya pengetahuan tentang diare, sehingga banyak kasus diare yang terjadi. Sebenarnya disebabkan karena kurang memadainya pengetahuan orangtua (ibu) balita. Tentang tindakan-tindakan, apa saja yang menurunkan insiden diare, sehingga diharapkan dengan pengetahuan tersebut Ibu dapat mengambil keputusan untuk meminimalisir resiko atau hal-hal yang menyebbkan diare. Di Puskesmas Bahu Manado angka kejadian diare selama 3 bulan terakhir ditemukan 64 kasus diare, maka setiap bulannya didapati 24 kasus diare.

\section{METODE PENELITIAN}

Jenis penelitian deskriptif cross sectional. Poulasi penelitian semua Ibu yang ada di Puskesmas Bahu Manado. Yang menjadi sampel penelitian yaitu IbuIbu yang membawa anaknya ke Poli Anak Puskesmas Bahu Manado. Penelitian dilakukan bulan November-desember 2012 dan dilakukan di Puskesmas Bahu Manado.

\section{HASIL PENELITIAN}

\section{Karakteristik Responden}

\section{Umur}

Tabel 1. Distribusi responden menurut kategori umur

\begin{tabular}{cll}
\hline Kategori Umur & $\mathbf{n}$ & $\mathbf{( \% )}$ \\
\hline$<20$ tahun & 7 & 9.1 \\
$21-30$ tahun & 42 & 54.5 \\
$31-40$ tahun & 20 & 26.0 \\
$>40$ tahun & 8 & 10.4 \\
Total & 77 & 100 \\
\hline
\end{tabular}


Berdasarkan Tabel 1, responden terbanyak adalah yang termasuk kategori umur 21-30 tahun sebanyak 42 orang (54.5\%), dan yang paling sedikit adalah responden dengan kategori umur $<20$ tahun sebanyak 7 orang (9.1\%).

\section{Pendidikan}

Tabel 2. Distribusi responden berdasarkan tingkat pendidikan

\begin{tabular}{lll}
\hline Pendidikan & n & $\mathbf{( \% )}$ \\
\hline SD & 5 & 6.5 \\
SMP & 14 & 18.2 \\
SMA & 49 & 63.6 \\
D3 & 4 & 5.2 \\
S1/SEDERAJAT & 5 & 6.5 \\
Total & 77 & 100 \\
\hline
\end{tabular}

Tabel 2 menunjukkan bahwa pada penelitian ini responden terbanyak memiliki tingkat pendidikan SMA sebanyak 49 orang (63.6\%) dan yang paling sedikit adalah responden dengan tingkat pendidikan Diploma III sebanyak 4 orang (5.2\%).

\section{Pekerjaan}

Tabel 3. Distribusi responden berdasarkan tingkat pekerjaan

\begin{tabular}{llll}
\hline Pekerjaan & n & (\%) & \\
\hline PNS & 5 & 6.5 & \\
SWASTA & 8 & 10.4 & \\
IRT & 64 & 83.1 & \\
Total & 77 & \multicolumn{2}{c}{100} \\
\hline
\end{tabular}

Pada Tabel 3 menunjukkan bahwa pada penelitian ini responden terbanyak dengan tingkat pekerjaan IRT sebanyak 64 orang (83.1\%) dan yang paling sedikit adalah responden dengan tingkat pekerjaan PNS sebanyak 5 orang (6.5\%).

\section{Pengetahuan}

Tabel 4. Distribusi responden berdasarkan tingkat pengetahuan

\begin{tabular}{ccc}
\hline $\begin{array}{c}\text { Tingkat } \\
\text { Pengetahuan }\end{array}$ & n & (\%) \\
\hline Kurang & 7 & 9.1 \\
Cukup & 27 & 35.1 \\
Baik & 43 & 55.8 \\
Total & 77 & 100 \\
\hline
\end{tabular}

Tabel 4 menunjukkan bahwa responden yang paling banyak adalah yang memiliki pengetahuan baik, yaitu sebanyak 43 orang $(55.8 \%)$, sedang yang memiliki pengetahuan cukup sebanyak 27 orang (35.1\%) dan yang memiliki pengetahuan cukup sebanyak 7 orang $(0,9 \%)$.

Tabel 5 menunjukkan bahwa 23 orang (29.9\%) responden yang memiliki pengetahuan baik termasuk dalam kategori umur 21-30 tahun. Responden yang memiliki pengetahuan cukup terbanyak adalah kategori umur 21-30 tahun yaitu sebanyak 17 orang (22.1\%). Pengetahuan kurang paling banyak dimiliki oleh kategori umur $<20$ tahun sebanyak 3 orang (3.9\%).

\section{Distribusi tingkat pengetahuan berdasarkan kategori umur}

Tabel 5. Distribusi tingkat pengetahuan berdasarkan kategori umur

\begin{tabular}{|c|c|c|c|c|c|c|c|c|}
\hline \multirow[t]{3}{*}{ Kategori Umur } & \multirow[b]{3}{*}{$\mathbf{n}$} & \multicolumn{6}{|c|}{ Tingkat Pengetahuan Ibu } & \multirow{3}{*}{$\begin{array}{l}\text { Total } \\
\%\end{array}$} \\
\hline & & \multicolumn{2}{|c|}{ Baik } & \multicolumn{2}{|c|}{ Cukup } & \multicolumn{2}{|c|}{ Kurang } & \\
\hline & & $\mathbf{n}$ & $\%$ & $\mathbf{n}$ & $\%$ & $\mathbf{n}$ & $\%$ & \\
\hline$<20$ tahun & 7 & 1 & 1.3 & 3 & 3.9 & 3 & 3.9 & 9.1 \\
\hline 21-30 tahun & 42 & 23 & 29.9 & 17 & 22.1 & 2 & 2.6 & 54.5 \\
\hline 31-40 tahun & 20 & 13 & 16.9 & 5 & 6.5 & 2 & 2.6 & 26.0 \\
\hline$>40$ tahun & 8 & 6 & 7.8 & 2 & 2.6 & 0 & 0 & 10.4 \\
\hline Total & 77 & 43 & 55.8 & 27 & 35.1 & 7 & 9.1 & 100 \\
\hline
\end{tabular}


Tabel 6. Distribusi tingkat pengetahuan berdasarkan kategori pendidikan

\begin{tabular}{|c|c|c|c|c|c|c|c|c|}
\hline \multirow[t]{3}{*}{ Kategori Pendidikan } & \multirow[b]{3}{*}{$\mathbf{n}$} & \multicolumn{6}{|c|}{ Tingkat Pengetahuan Ibu } & \multirow{3}{*}{$\begin{array}{c}\text { Total } \\
\quad \% \\
\end{array}$} \\
\hline & & \multicolumn{2}{|c|}{ Baik } & \multicolumn{3}{|c|}{ Cukup } & \multirow{2}{*}{$\begin{array}{c}\text { Kurang } \\
\%\end{array}$} & \\
\hline & & $\mathbf{n}$ & $\%$ & $\mathbf{n}$ & $\%$ & $\mathbf{n}$ & & \\
\hline SD & 5 & 1 & 1.3 & 2 & 2.6 & 2 & 2.6 & 6.5 \\
\hline SMP & 14 & 6 & 7.8 & 6 & 7.8 & 2 & 2.6 & 18.2 \\
\hline SMA & 49 & 29 & 37.7 & 7 & 22.1 & 3 & 3.9 & 63.6 \\
\hline D3 & 4 & 3 & 3.9 & 1 & 1.3 & 0 & 0 & 5.2 \\
\hline S1/SEDERAJAT & 5 & 4 & 5.2 & 1 & 1.3 & 0 & 0 & 6.5 \\
\hline Total & 77 & 43 & 55.8 & 27 & 35.1 & & $\begin{array}{ll}7 & 9.1\end{array}$ & 100 \\
\hline
\end{tabular}

Tabel 7. Distribusi tingkat pengetahuan berdasarkan kategori pekerjaan

\begin{tabular}{|c|c|c|c|c|c|c|c|c|}
\hline \multirow{3}{*}{$\begin{array}{l}\text { Kategori } \\
\text { Pekerjaan }\end{array}$} & \multirow[b]{3}{*}{$\mathbf{n}$} & \multicolumn{6}{|c|}{ Tingkat Pengetahuan Ibu } & \multirow{3}{*}{$\begin{array}{l}\text { Total } \\
\%\end{array}$} \\
\hline & & \multicolumn{2}{|c|}{ Baik } & \multicolumn{2}{|c|}{ Cukup } & \multicolumn{2}{|c|}{ Kurang } & \\
\hline & & $\mathbf{n}$ & $\%$ & $\mathbf{n}$ & $\%$ & $\mathbf{n}$ & $\%$ & \\
\hline PNS & 5 & 5 & 6.5 & 0 & 0 & 0 & 0 & 6.5 \\
\hline SWASTA & 8 & 6 & 7.8 & 2 & 2.6 & 0 & 0 & 10.4 \\
\hline IRT & 64 & 32 & 41.6 & 25 & 32.5 & 7 & 9.1 & 83.1 \\
\hline Total & 77 & 43 & 55.8 & 27 & 35.1 & 7 & 9.1 & 100 \\
\hline
\end{tabular}

Tabel 6 menunjukkan bahwa responden yang paling banyak pengetahuan baik memiliki tingkat pendidikan setingkat SMA sebanyak 29 orang (37.7\%). Sebanyak 17 orang (22.1\%) responden yang memiliki pengetahuan cukup merupakan lulusan SMA. Pengetahuan kurang paling banyak dialami oleh responden dengan tingkat pendidikan SMA sebanyak 3 orang (3.9\%).

Tabel 7 menunjukkan bahwa 32 orang (41.6\%) responden yang pengetahuannya baik termasuk dalam kategori pekerjaan IRT. Pengetahuan cukup terbanyak adalah responden dengan pekerjaan IRT yaitu sebanyak 25 orang (32.5\%) dan yang berpengetahuan kurang sebanyak 7 orang (9.1\%) dengan pekerjaan IRT.

\section{BAHASAN}

\section{Karakteristik Responden}

\section{Umur}

Berdasarkan hasil yang diperoleh dari kuesioner yang disebarkan kepada 77 responden menunjukan bahwa kategori umur terbanyak adalah kelompok umur 2130 tahun sebanyak 42 orang (54.5\%), dan yang paling sedikit adalah responden dengan kategori umur $<20$ tahun sebanyak 7 orang (9.1\%). Hal ini membuktikan bahwa semakin cukup umur sesorang maka akan semakin matang dalam berfikir dan bekerja. Dari segi kepercayaan masyarakat, orang yang dewasa akan lebih dipercaya dibandingkan dengan yang belum dewasa, oleh sebab tingkat pengetahuan seseorang dapat diukur melalui segi kedewasaan, sehingga dalam memberikan pelayanan dapat mengaplikasikan prosedur-prosedur pelayanan dengan baik serta mampu menerapkan profesionalisme dalam pemberian pelayanan. Hasil analisa sesuai dengan teori bertambahnya usia, maka tingkat perkembangan akan sesuai dengan tingkat pengetahuan yang pernah didapat juga dari pengalaman sendiri dan menurut Hurlock pada umur dua puluh seseorang talah memiliki kemampuan mental yang diperlukan untuk mempelajari dan menyesuaikan diri pada situasi yang baru, misalnya mengingat hal-hal yang dulu pernah dipelajari, penalaran analogis dan 
berfikir kreatif, sekitar awal atau pertengahan tiga puluh tahun, kebanyakan orang mudah mampu menyelesaikan masalah-masalah mereka dengan cukup baik sehingga menjadi stabil, tenang dan secara emosional. ${ }^{7}$

\section{Pendidikan}

Berdasarkan hasil penelitian tingkat pendidikan terbanyak adalah setingkat SMA sebanyak 49 orang (63.6\%) dan yang terendah adalah setingkat Diploma III sebanyak 4 orang (5.2\%). Hal ini sejalan dengan Hasil analisis ini bahwa semakin tinggi pendidikan atau pengetahuan seseorang maka semakin terampil dalam menyikapi pekerjaannya dan menghasilkan kinerja yang diharapkan, sedangkan semakin rendah pendidikan atau pengetahuan sesorang maka semakin tidak terampil dalam menyikapi pekerjaannya. ${ }^{8}$

\section{Pekerjaan}

Berdasarkan hasil penelitian kategori pekerjaan terbanyak adalah responden dengan kategori IRT yaitu sebanyak 64 orang (83.1\%) dan yang paling sedikit adalah responden dengan pekerjaan PNS sebanyak 5 orang (6.5\%). Seseorang yang telah bekerja sekian lama akan mampu melakukan penyesuaian diri terhadap lingkungan pekerjaannya sehingga dapat mencapai kepuasan dalam menjalankan pekerjaannya. ${ }^{8}$ Hal ini menunjukan bahwa semakin terampil petugas dalam menjalankan tugas pokok dan fungsi yang diemban maka akan menghasilkan kinerja yang diinginkan. Tetapi semakin tidak terampil petugas dalam menjalankan tugas pokok dan fungsi maka akan semakin tidak sesuai dengan kinerja yang diinginkan. Dalam istilah yang lebih mudah, seorang yang terbiasa menjalani sebuah pekerjaan lama kelamaan akan merasa betah dan tidak mengeluh dengan pekerjaannya dan akan sampai pada tingkat menyenangi dan mencintai pekerjaannya ${ }^{9}$

\section{Pengetahuan}

Berdasarkan hasil penelitian yang dilakukan peneliti, diketahui bahwa mayoritas responden memiliki pengetahuan baik terhadap kejadian diare pada anak di Puskesmas Bahu Manado yaitu sebanyak 43 orang (55.8\%) dan minoritas yang berpengetahuan kurang sebanyak 7 orang (9.1\%). Hal ini sama menurut teori bahwa Pengetahuan merupakan landasan utama dan penting dalam pelaksanaan pelayanan. Pengetahuan seseorang dapat diperoleh dengan berbagai usaha, baik sengaja maupun secara kebetulan. Usaha yang dilakukan dengan sengaja meliputi berbagai metode dan konsep baik melalui proses pendidikan maupun melalui pengalaman $^{10}$

\section{SIMPULAN}

Dari penelitian yang telah dilakukan dapat disimpulkan bahwa pengetahuan Ibu tentang diare pada anak sebagian mendapat nilai baik.Hendaknya lebih ditingkatkan penyuluhan kesehatan mengenai penyakit diare kepada Ibu-Ibu yang membawa bayinya ke Puskesmas.

\section{UCAPAN TERIMA KASIH}

Dan kepada semua pihak baik secara langsung maupun tidak langsung telah membubuhkan ide, gagasan pada penulis sehingga penulis dapat menyelesaikan artikel ini.

\section{DAFTAR PUSTAKA}

1. Soekanto, M. Definisi Pengetahuan http://www.alhassain.co m/ indo nesian / articles/articles/philosopyandgratitudelibra ry/definisipengetahuan/001.html ; 2003

2. Breese JF, Wang B LE, Soenarto Y, Nelson EA, Tam J, Wilopo SA et al. First report from the Asian Rotavirus Survaillance Network. Emerg Inf Dis; 2004. Hal 525-37.

3. Parashar UD, Hummelman EG, Breese JF, Miller MA, Glass RI. Global Illness and Death Caused by Rotavirus Disease in children. Emerg Inf Dis; 2006. Hal 565-72. 
4. Ummuauliya.

Keperawatan ml.scribd.com/doc/42139432/diare pada tanggal 08 februari 2009

5. Dinas Kesehatan. Data angka diare di Indonesia. diakses

dari http://www.infodokterku .com/indexphp?option=com_content\&view=article\&i d=201=data-angka-diare-diindonesia\&catid $=40=$ data\&itemid $=54$ diakses pada tanggal 15 oktober 2012; 2011

6. Simatupang. Perawatan tali pusat dan Penanganan diare http:/ /book s.google.co.id/books?id=An8r5THqAyuc \&pg=pA2\&Ipg=PA2\&dg=simatupang +20 04+diare\&source=bl\&ots=DwMub_a_98 \&sig $=\mathrm{x} 4 \mathrm{dsBxtHjMx5yqf}$ diakses pada taggal 15 oktober 2012; 2004

7. Notoatmodjo, S. Ilmu Kesehatan Masyarakat. Jakarta : Rineka Cipta; 2003. Hal 261-62

8. Subawa, Nyoman Sri \& Budiarta. Analisis perbedaan prestasi kerja terhadap tingkat pendidikan dan masa kerja www.undiknas.ac.id ; 2008

9. Wardiah, Handono, Subargus. Sumber daya manusia dan kinerja www.irckmpk.ugm.ac.id ; 2008

10. Setiawan. Hubungan tingkat pengetahuan sikap dengan perilaku http://www.pdffinder.com 